\title{
TINJAUAN NORMA HUKUM JUSTICE COLLABORATOR DAN WHISTLEBLOWER PADA TINDAK PIDANA KORUPSI
}

\author{
Esti Kanti Pertiwi \\ Magister Ilmu Hukum, Universitas Muhammadiyah Yogyakarta \\ e-mail: estikp2403@gmail.com \\ Noor Rahmad \\ Magister Ilmu Hukum, Universitas Muhammadiyah Yogyakarta \\ e-mail: noorrahmad222@gmail.com
}

\begin{abstract}
ABSTRAK
Penelitian ini bertujuan untuk mengetahui formulasi norma hukum pada justice collaborator dan whistleblower dalam tindak pidana korupsi dan pelaksanaannya. Hukum pidana memberikan peluang bagi pelaku tindak pidana agar menjadi justice collaborator dan mau bekerja sama dengan penegak hukum, dimana bentuk apresiasinya adalah mereka bisa dipertimbangkan untuk diberikan perlindungan dan keringanan hukuman. Istilah justice collaborator sering disalahartikan dengan whistleblower. Norma tentang whistleblower dan justice collaborator sudah diatur dalam peraturan bersama, SEMA dan UU No. 31 Tahun 2014, pada pelaksanaannya masih ada kelemahan-kelemahan yang disebabkan berbeda-beda penafsiran dari peraturan yang ada oleh penegak hukum. Penelitian ini menggunakan penleitian hukum normatif dengan pendekatan undang-undang. Hasil penelitian ini mengungkapkan bahwa peraturan yang ada masih memiliki kelemahan dalam mengatur justice collaborator dan whistleblower. Justice collaborator dan whistleblower berperan penting dalam memberikan informasi untuk mengungkap suatu tindak pidana korupsi. Peran penting dari justice collaborator dan whistleblower menimbulkan ancaman, sehingga perlu diberikan perlindungan dari penegak hukum dan diberikan penghargaan, seperti pengurangan hukuman bagi justice collaborator.
\end{abstract}

Kata Kunci: justice collaborator; whistleblower; korupsi

\section{ABSTRACT}

The study aims to determine the formulation of legal norms on justice collaborator and whistleblower in corruption and their implementation. JCriminal law provides an opportunity for criminal offenders to become justice collaborators and want to cooperate with law enforcement, where the form of appreciation is that they can be considered for protection and relief from punishment. The term justice collaborator is often confused with whistleblowers. the norms regarding whistleblowers and justice collaborators are already regulated in a joint regulation, SEMA and Law No. 31/2014, in its implementation there are still weaknesses caused by different interpretations of existing regulations by law enforcement. This research uses normative legal research with a statute approach.. The results of this study reveal that the existing regulations still have weaknesses in regulating justice collaborators and whistleblowers. Justice collaborator and whistleblower play an important role in providing information to uncover a corruption. the important role of justice collaborator and whistleblower creates threats, so it needs to be given protection from law enforcers and given respect, such as reducing penalties for justice collaborators.

Keywords: Justice Collaborator; Whistleblower; Corruption 


\section{PENDAHULUAN}

Menemukan fakta kebenaran dalam suatu tindak pidana khususnya pada kasus yang berasal dari kelompok intelektual atau mereka yang memiliki jabatan tinggi sangat sulit. Proses pencarian dan penemuan fakta-fakta juga sulit diperoleh, sehingga hal itulah yang membuat pengungkapan dan penanganan kasus menjadi tertunda, lamban, dan bahkan menghilang ditelan waktu. Tindak pidana yang pengungkapannya sulit diantaranya tindak pidana korupsi, narkotika, terorisme, perdagangan manusia dan tindak pidana lain yang bersifat terorganisir.

Untuk menyelesaikan kasus yang terorganisir, perlu adanya pihak yang bekerjasama dengan penegak hukum. Pada hukum pidana terdapat peluang bagi pelaku kejahatan untuk bekerjasama sebagai saksi dalam mengungkap kejahatan. Pelaku yang dapat bekerjasama bersama polisi atau penegak hukum dapat diberikan pertimbangan keringanan hukuman serta perlindungan saksi. Pihak saksi yang mau bekerjasama dengan penegak hukum dinamakan justice collaborator. ${ }^{1}$

Istilah justice collaborator (selanjutnya disebut JC) sering disalahartikan dengan whistleblower (selanjutnya disebut WB). Antara JC dan WB memiliki status hukum yang berbeda. Karena keduanya hampir sangat mirip, maka sebagai pembeda antara whistleblower dan justice collaborator diciptakan sebuah peraturan yang disetujui oleh beberapa lembaga penegak hukum, yaitu Kemenkumham, Kejaksaan Agung, Kepolisian, KPK, LPSK. Peraturan yang dibuat ditujukan untuk mengatur terkait perlindungan saksi pelapor dan saksi pelaku yang mau bekerjasama dengan penegak hukum. ${ }^{2}$ Peraturan lain terkait dengan JC dan WB dibuat pada Surat Edaran Mahkamah Agung (SEMA) No. 4 Tahun 2011 tentang Perlakuan Bagi Pelapor Tindak Pidana (Whistleblower) dan Saksi Pelaku yang Bekerjasama (Justice Collaborators) di dalam Perkara Tindak Pidana Tertentu.

JC dan WB di Indonesia memperoleh perlindungan dan pemenuhan hak-haknya dalam

${ }^{1}$ Firman Wijaya. (2012). Whistle Blower dan Justice Collaborator dalam Perspektif Hukum. Jakarta: Penaku, h. 7.

2 Fadli Razeb Sanjani. (2015). "Penerapan Justice Collaborator dalam Sistem Peradilan Pidana di Indonesia”. JOM Fakultas Hukum, 2(2), h. 1-14. proses peradilan. Justice collaborator dilindungi di berbagai tahap persidangan, yaitu sebelum persidangan (pra ajudikasi), tahap persidangan di pengadilan (ajudikasi), dan pada tahap sesudah persidangan (post ajudikasi). Sesuai UU No. 31 Tahun 2014 atas perubahan pada UU No. 13 Tahun 2016 tentang Perlindungan Saksi dan Korban, justice collaborator memperoleh hak perlindungan oleh penegak hukum, seperti Lembaga Pemasyarakatan, LPSK dan KPK. ${ }^{3}$

Meski norma tentang JC dan WB sudah diatur dalam peraturan bersama, SEMA dan UU No. 31 Tahun 2014, pada pelaksanaannya masih ada kekurangan-kekurangan yang dikarenakan adanya perbedaan penafsiran pada peraturan yang ada oleh penegak hukum. Sebagai contoh, kasus yang terjadi pada Nazaruddin yang di pidana kurungan selama 13 tahun untuk 2 kasus. Kasus Nazaruddin yang pertama yaitu terbuktinya atas penerimaan suap sejumlah 4,6 miliar rupiah, yang diberikan oleh M El Idri sebagai Manajer Pemasaran PT Duta Graha Indah. Atas kasus pertama Nazaruddin memperoleh hukuman 7 tahun kurungan serta denda 300 juta rupiah. Kasus berikutnya Nazaruddin terbukti atas gratifikasi dan pencucian uang. Nazaruddin kemudian divonis enam tahun penjara serta denda sejumlah satu miliar rupiah. Dari kedua kasus tersebut, Nazaruddin divonis 13 tahun penjara serta denda sejumlah 1,3 miliar rupiah. ${ }^{4}$

Pada 14 Juni 2020, Nazaruddin dibebaskan dari Lapas Sukamiskin karena memperoleh remisi 45 bulan 120 hari (4 tahun 1 bulan). Remisi diperoleh berkat perannya sebagai justice collaborator yang mengungkapkan informasi penting, remisi yang diperolehnya direspon Kemenkumham sesuai dalam ketentuan dalam PP No. 99 Tahun 2012. ${ }^{5}$ Penetapan Nazaruddin sebagai justice collaborator didasarkan

${ }^{3}$ Jupri. (2018). "Reward Keringanan Sanksi Pidana Bagi Justice Collaborator Perkara Korupsi”. Jurnal Transformative, 4(1), h. 13-32.

4 Rakhmad Hidayahtulloh Permana. "Jadi Justice Collaborator-Dapat Remisi 4 Tahun, Ini yang Diungkap Nazaruddin". available from https://news.detik.com/ berita/d-5056933/jadi-justice-collaborator-dapat-remisi-4tahun-ini-yang-diungkap-nazaruddin/2, diakses 1 Mei 2020.

5 CNN Indonesia. "Soal Nazaruddin bebas, Yasonna Berdalih Ada Surat KPK". available from https://www. cnnindonesia.com/nasional/20200623002626-12-516220/soalnazaruddin-bebas-yasonna-berdalih-ada-surat-kpk, diakses pada 2 Mei 2020. 
pada surat Nomor R-2250/55/06/2014 tanggal 9 Juni 2014 perihal surat keterangan atas nama Muhammad Nazaruddin dan Surat Nomor R.2576/55/06/2017 tanggal 21 Juni 2017 perilah permohonan keterangan telah bekerja sama dengan penegak hukum atas nama Mohammad Nazaruddin.

Di sisi lain Wakil Ketua KPK Alexander Marwata mengatakan bahwa KPK tidak pernah menetapkan Nazaruddin sebagai justice collaborator, meskipun mengakui adanya kedua surat di atas. Menurut pandangan KPK, yang diterbitkan bukan surat ketetapan sebagai justice collaborator. Plt Juru Bicara KPK Ali Fikri menjelaskan dua surat perihal atas nama M. Nazaruddin dikarenakan telah mengungkap sejumlah perkara korupsi, yakni pembangunan Pusat Pendidikan dan Pelatihan Sarana Olahraga Nasional (P3SON) Hambalang, pengadaan e-KTP di Kemendagri, perkara dengan terdakwa Anas Urbaningrum. Kasus-kasus yang diungkap oleh Nazaruddin bukan menjadi kasus dia sebagai terpidana melainkan mengungkapkan kasus-kasus lain, dan KPK tidak pernah memberi status justice collaborator. ${ }^{6}$ Lebih lanjut pihak KPK menjelaskan bahwa Nazaruddin sebagai whistleblower. ${ }^{7}$

Kemenkumham salah memahami posisi Nazaruddin. Menurutnya Nazaruddin memang bukan sebagai justice collaborator melainkan whistleblower. Definisi dari whistleblower sendiri adalah seseorang yang mengetahui suatu tindak pidana dan melaporkannya kepada penegak hukum. Sementara justice collaborator termasuk pelaku meskipun bukan yang utama, tetapi mengungkapkan bahwa dirinya sebagai pelaku juga dan mau memberikan keterangan sebagai saksi. ${ }^{8}$

Polemik yang terjadi terkait dengan remisi yang diperoleh Nazaruddin berpotensi meresahkan.

\footnotetext{
${ }^{6}$ Ibnu Hariyanto. "Pimpinan KPK: Nazaruddin Bukan Justice Collaborator, Tapi Whistleblower". available from https:// news.detik.com/berita/d-5065463/pimpinan-kpk-nazaruddinbukan-justice-collaborator-tapi-whistleblower/1, diakses pada 1 Mei 2020

${ }^{7}$ Alfian Putra Abdi. "KPK: Nazaruddin Bukan Justice Collaborator Melainkan Whistleblower". available from https://tirto.id/kpk-nazaruddin-bukan-justice-collaboratormelainkan-whistleblower-fKPR?utm_source =Tirtoid\&utm medium=Terkait, Diakses pada 2 Mei 2020.

8 Alfian Putra Abdi. "Silang Pendapat KPK dan Kemenkumham Soal Cuti Bebas Nazaruddin". available from https://tirto.id/silang-pendapat-kpk-dan-kemenkumham-soalcuti-bebas-nazaruddin-fJAu, diakses pada 2 Mei 2020.
}

Pasalnya Nazaruddin sudah merugikan negara lewat kasus Wisma Atlet sebesar Rp 54,7 miliar. Peneliti dari Indonesia Corupption Watch (ICW) Kurnia Ramadhana menyoroti bahwa pemberian remisi bagi Nazaruddin tidak sesuai dengan Pasal 34 A ayat (1) huruf a PP No. 99 Tahun 2012 sebab Nazaruddin tidak pernah ditetapkan sebagai justice collaborator. Kurnia berpendapat bahwa polemik ini menunjukkan Kemenkumham tidak mendukung upaya pemberantasan korupsi dan memanjakan narapidana koruptor. ${ }^{9}$

Pada hakikatnya baik justice collaborator maupun whistleblower memberikan peran yang besar untuk mengungkap praktik korupsi di lembaga negara. Apabila sistem JC dan WB ini tidak ada, tentu peran serta masyarakat dalam mengungkap dugaan tindak pidana menjadi rendah. Hal ini dikemukakan oleh Abdul Haris Semendawai yang mendorong peran pelapor di Indonesia. Peran JC dan WB di Indonesia perlu dibangun, khususnya dalam aspek perlindungannya. Risiko dari pelapor yaitu dapat memperoleh ancaman dari kesaksiannya yang dilaporkan. Pelaku yang dilaporkan tentu merasa dirugikan, sehingga ada rasa ingin membalas dendam atau menghalang-halangi pelapor untuk memberikan laporannya kepada penegak hukum. Bahkan mereka yang merasa dirugikan tidak menutup kemungkinan dapat mengancam dan balas dendam. ${ }^{10}$

Berdasarkan pada asas kesamaan dalam hukum, saksi atau pelapor dalam tindak pidana korupsi harus diberikan perangkat hukum. Peraturan Bersama, SEMA No. 4 Tahun 2011 dan UU No. 31 Tahun 2014 yang mengatur JC dan WB, dalam pelaksanaannya menimbulkan masalah dan perbedaan pendapatan pandangan antara JC dan EB. Ada perbedaan persepsi antara Kemenkumham dan KPK perihal status remisi yang diberikan kepada Nazaruddin. Perbedaan ini timbul karena perbedaan pandangan oleh lembaga penegak hukum, yaitu terkait status Nazaruddin dalam perannya apakah sebagai JC atau WB.

Artikel ini membahas mengenai norma hukum JC dan WB pada tindak pidana korupsi. Norma hukum pada dasarnya inheren dengan nilai-nilai yang diyakini oleh masyarakat, tetapi daya dan kekuatan

9 ibid.

10 Abdul Haris Semendawai. (2011). Memahami Whistleblower. Jakarta: Lembaga Perlindungan Saksi dan Korban (LPSK), h. 14-15. 
keberlakuan hukum, tidak dapat melepaskan diri dari kelembagaan kekuasaan, sehingga hukum, masyarakat, dan kekuasaan merupakan unsur dari suatu tatanan masyarakat. ${ }^{11}$ Payung hukum yang mengatur tentang penetapan JC dan WB diatur pada Undang-Undang Perlindungan Saksi dan Korban, tetapi belum ada peraturan yang menyatakan syarat penetapan status JC dan WB secara gamblang atau tegas sehingga perlu ditata ulang agar kepastian hukum dan keadilan terjamin.

\section{PERUMUSAN MASALAH}

Formulasi norma hukum yang mengatur whistleblower dan justice collaborator pada peraturan perundang-undangan, serta bagaimana pelaksanaannya pada pelaku tindak pidana korupsi.

\section{METODE PENELITIAN}

Penelitian ini merupakan penelitian hukum normatif. Pendekatan yang digunakan melalui peraturan perundang-undangan.

\section{PEMBAHASAN}

Hukum secara umum bertujuan untuk memperoleh keadilan, menjamin adanya kepastian hukum dan mendapatkan manfaat atas dibentuknya hukum. Unsur-unsur yang terdiri dari keadilan, kepastian hukum dan kemanfaatan perlu dipertimbangkan dan dilaksanakan pada proses penegakan hukum, sehingga tidak menyebabkan ketimpangan.

Artikel ini menggunakan asas Equality Before the Law, yang memiliki arti tentang asas persamaan kesederajatan di muka hukum. Pada asas ini dijelaskan tentang setiap orang dari berbagai jenis kalangan, baik itu orang kaya atau orang miskin, dengan jabatan tinggi atau rendah, ketika masuk dalam proses pemeriksaan dengan penyidik, penuntutan, dan pemeriksaan pengadilan memiliki hak yang sama dalam memperoleh perlakuan.

Asas hukum ini digunakan agar diterapkan oleh penegak hukum dalam menentukan seseorang menjadi justice collaborator atau whistleblower. Keduanya memiliki peran dalam memberikan informasi penting, tetapi memiliki hak yang berbeda.

\footnotetext{
${ }^{11}$ Zainal Arifin Hoesein. (2012). "Pembentukan Hukum dalam Perspektif Pembaruan Hukum". Jurnal RechtsVinding. 1(3), h. 307-327.
}

\section{Formulasi Norma Hukum Pengaturan Justice Collaborator dan Whistleblower}

Pengaturan mengenai JC dan WB merupakan salah satu terobosan yang baru. Mengenai JC dan WB baik dalam undang-undang tentang pemberantasan korupsi dan undang-undang lainnya secara eksplisit tidak mengatur mengenai JC dan WB dalam peradilan pidana. Menurut Manulu isitlah JC dan WB terlebih dahulu dikenal dalam praktik penegakan hukum pidana dan kemudian mulai diatur dalam hukum positif Indonesia. ${ }^{12}$

Berikut dijelaskan mengenai pengaturan hukum terkait dengan JC dan WB, yang sumbernya berasal dari dokumen internasional, dan yang ada pada peraturan nasional sebagai berikut:

1. United Nations Convention Against Corruption/ UNCAC (Undang-Undang Nomor 7 Tahun 2006 tentang Konvensi PBB Anti Korupsi)

Latar belakang utama mengapa ada pengaturan mengenai JC dan WB dalam sistem peradilan pidana adalah instrumen ini. Pengaturan berkaitan dengan $J C$ dan $W B$ dalam peradilan pidana di atur dalam pasal 37 sebagai berikut:

Ayat (2): setiap negara peserta wajib mempertimbangkan, memberikan kemungkinan dalam kasus-kasus tertentu mengurangi hukuman dari seorang pelaku yang memberikan kerjasama yang substansial dalam penyelidikan atau penuntutan suatu kejahatan yang diterapkan dalam konvensi ini.

Ayat (3): setiap negara wajib mempertimbangkan kemungkinan sesuai dengan prinsip-prinsip dasar hukum nasionalnya untuk memberikan kekebalan dari penuntutan bagi orang yang memberikan kerjasama substansial dalam penyelidikan atau penuntutan suatu tindak pidana yang diterapkan dalam konvensi ini. ${ }^{13}$

Indonesia yang diwakili oleh Presiden Indonesia ikut menandatangani persetujuan pengikatan pada konvensi ini pada tahun 2006. Hingga saat ini 80 persen dari aturan yang dituangkan dalam UNCAC sudah diterapkan di Indonesia. Tujuan utama dari UNCAC yaitu meningkatkan dan memperkuat pencegahan dan penindakan korupsi

${ }^{12}$ River Yohanes Manalu. (2015). "Justice Collaborator dalam Tindak Pidana Korupsi”. Lex Crimen, 4(1), h. 152-163.

${ }^{13}$ United Nations Convention against Corruption (UNCAC) Pasal 37 ayat (2) dan (3), h. 27. 
agar lebih efektif dan efisien juga meningkatkan dan mendorong kerjasama internasional dan bantuan teknis untuk pencegahan dan penindakan korupsi dan meningkatkan integritas, akuntabilitas, dan manajemen pemerintahan. ${ }^{14}$

Kaitannya aturan UNCAC dengan JC dan WB di Indonesia yaitu, ingin mendorong partisipasi masyarakat untuk mengungkapkan tindak pidana korupsi. Korupsi yang masuk dalam white collar crime jika hanya melibatkan penegak hukum saja sulit untuk diungkap, sedangkan dengan adanya bantuan JC dan WB dapat mengungkap kasuskasus yang tentunya melibatkan orang-orang besar tertentu. ${ }^{15}$

\section{United Nations Convention Against} Transnasional Organized Crime/UNCATOC (Undang-Undang Nomor 5 Tahun 2009 tentang Konvensi PBB Anti Kejahatan Transnasional Terorganisir)

Konvensi selanjutnya adalah UNCATOC yang dilaksanakan pada 2009. Konvensi ini bertujuan untuk menjalin kerjasama antar negara. Karena kejahatan antar negara yang terorganisir mengancam kondisi ekonomi, sosial, politik, keamanan dan perdamaian dunia. Pada konvensi ini pula memberikan ide mengenai pengaturan JC dan WB dalam peradilan pidana, yaitu diatur dalam Pasal 26 berikut:

Ayat (2): setiap negara wajib mempertimbangkan untuk membuka kemungkinan, dalam keadaan yang tepat, pengurangan hukuman atas tertuduh yang memberikan kerjasama yang berarti dalam penyelidikan atau penuntutan atas tindak pidana yang tercakup oleh konvensi ini.

Ayat (3): setiap negara wajib mempertimbangkan untuk membuka kemungkinan, sesuai dengan prinsip-prinsip dasar hukum nasionalnya, pemberian kekebalan atas penuntutan terhadap seseorang yang memberikan kerjasama yang berarti di dalam penyelidikan atau penuntutan atas tindak pidana yang tercakup oleh konvensi ini.

14 ibid.

15 Hambali Thalib, Sufirman Rahman, dan Abdul Haris Semendawai. (2017). "The Role of Justice Collaborator in Uncovering Criminal Case in Indonesia". Diponegoro Law Review,2(1), h. 1-16.
Pokok paling penting dalam aturan dari konvensi ini tertuang pada Pasal 12 ayat (1) tentang perampasan dan penyitaan aset tindak pidana yang antara lain menjelaskan:

Negara-negara wajib mengambil sepanjang dimungkinkan dalam sistem hukum nasionalnya, tindakan yang dianggap perlu guna memungkinkan perampasan atas:

a. Hasil tindak pidana yang berasal dari tindak pidana yang tercakup dalam konvensi ini atau kekayaan yang nilainya sama dengan hasil tindak pidana tersebut.

b. Kekayaan, peralatan, atau sarana lainnya yang digunakan atau ditujukan untuk digunakan dalam tindak pidana yang tercakup dalam konvensi ini.

Adanya aturan tersebut maka kerugian negara yang disebabkan tindak pidana korupsi dapat diminimalkan atau dikembalikan seluruhnya. Pada ayat (2) juga dipertegas bahwa: setiap negara pihak wajib mengambil upaya yang dianggap perlu guna memungkinkan identifikasi, pelacakan, pembekuan atau penyitaan barang apa pun yang dimaksud dalam ayat (1) pasal ini untuk tujuan akhir perampasan.

3. Undang-Undang Nomor 13 Tahun 2006 tentang Perlindungan Saksi dan Korban

Tujuan dibuatnya undang-undang ini adalah untuk meningkatkan partisipasi masyarakat dalam mengungkap tindak pidana. Untuk meningkatkan tersebut perlu dibuat iklim yang kondusif dengan memberikan jaminan hukum dan keamanan kepada setiap pihak yang mengetahui dan menemukan dugaan tindak pidana serta mau melaporkannya kepada penegak hukum.

Pihak yang memberikan pelaporan mengenai tindak pidana berpotensi memperoleh ancaman dari pihak lain yang terkait, untuk itu perlu diberikan perlindungan hukum dan keamanan yang memadai atas laporannya. Memberikan jaminan perlindungan bagi JC dan WB penting diberikan, karena dapat memberikan perasaan aman di masyarakat, sehingga mereka tidak perlu takut untuk memberikan laporan terkait dengan tindak pidana yang diketahuinya.

Menurut Hikmawati, disebutkan bahwa undangundang ini diperlukan karena mengingat pentingya keterangan saksi dan/atau korban sebagai salah satu alat bukti dalam upaya mencari dan menemukan 
kejelasan tentang tidak pidana yang dilakukan oleh pelaku tindak pidana. Penegak hukum sering mendapat kesulitan dalam menghadirkan saksi dan/ atau korban, karena mereka sering mendapat ancaman fisik ataupun psikis dari pihak yang dilaporkan. ${ }^{16}$

Sebelum pembentukan UU No. 13 Tahun 2006, kebijakan perlindungan saksi untuk tindak pidana tertentu telah diatur dalam berbagai peraturan perundang-undangan. Dalam peraturan-peraturan tersebut terdapat perbedaan para pihak yang perlu mendapat perlindungan. Dalam pelanggaran HAM misalnya, perlindungan saksi dan korban diatur dalam Pasal 4 Peraturan Pemerintah (PP) No. 2 Tahun 2002 tentang Tata Cara Perlindungan Terhadap Korban dan Saksi dalam Pelanggaran HAM yang Berat (peraturan pelaksana ketentuan Pasal 34 ayat (3) UU No. 26 Tahun 2000 tentang Pengadilan HAM), perlindungan saksi tindak pidana pencucian uang diatur dalam Pasal 5 PP No. 57 Tahun 2003 tentang Tata Cara Perlindungan Khusus bagi Pelapor dan Saksi Tindak Pidana Pencucian Uang (peraturan pelaksana ketentuan Pasal 40 ayat (2) dan Pasal 42 ayat (2) UU No. 15 Tahun 2002 tentang Tindak Pidana Pencucian Uang sebagaimana telah diubah dengan UU No. 25 Tahun 2003), dan perlindungan saksi tindak pidana terorisme diatur dalam Pasal $3 \mathrm{PP}$ No. 24 Tahun 2003 tentang Tata Cara Perlindungan Terhadap Saksi, Penyidik, Penuntut Umum, dan Hakim dalam Perkara Tindak Pidana Terorisme (peraturan pelaksana ketentuan Pasal 33 dan Pasal 34 UU Nomor 15 Tahun 2003 tentang Penetapan PP Pengganti UU Nomor 1 Tahun 2002 tentang Pemberantasan Tindak Pidana Terorisme, Menjadi Undang-Undang). ${ }^{17}$

Khusus untuk tindak pidana korupsi, perlindungan saksi diatur dalam Pasal 41 ayat (2) huruf e UU No. 31 Tahun 1999 tentang Pemberantasan Tindak Pidana Korupsi, yang menyebutkan bahwa "masyarakat yang berperan serta membantu upaya pencegahan dan pemberantasan tindak pidana korupsi berhak mendapat perlindungan hukum, dalam hal diminta hadir dalam proses penyelidikan, penyidikan, dan di sidang pengadilan sebagai saksi pelapor, saksi, atau saksi ahli, sesuai dengan ketentuan peraturan

16 Puteri Hikmawati. (2013). “Upaya Perlindungan Whistleblower dan Justice Collaborator dalam Tindak Pidana Korupsi”. Negara Hukum. 4(1), h. 87-104.

${ }^{17}$ ibid. perundang-undangan yang berlaku." Selain itu, UU No. 30 Tahun 2002 tentang Komisi Pemberantasan Tindak Pidana Korupsi juga mengatur perlindungan saksi. Pasal 15 UU No. 30 Tahun 2002 menyebutkan "Komisi Pemberantasan Korupsi berkewajiban memberikan perlindungan terhadap saksi atau pelapor yang menyampaikan laporan ataupun memberikan keterangan mengenai terjadinya tindak pidana korupsi." 18

Adapun peraturan pelaksana dari ketentuan mengenai peran serta masyarakat dalam pencegahan dan pemberantasan tindak pidana korupsi dalam UU No. 31 Tahun 1999 adalah PP No. 71 Tahun 2000 tentang Tata Cara Pelaksanaan Peran Serta Masyarakat dan Pemberian Penghargaan dalam Pencegahan dan Pemberantasan Tindak Pidana Korupsi. Pasal 5 ayat (1) PP tersebut mengatakan bahwa "Setiap orang, Organisasi Masyarakat, atau Lembaga Swadaya Masyarakat, yang memberikan informasi disertai keterangan mengenai dugaan pelaku tindak pidana korupsi, berhak atas perlindungan hukum baik mengenai status hukum maupun rasa aman." Tetapi perlindungan hukum tidak diberikan apabila dari hasil penyelidikan atau penyidikan terdapat bukti yang cukup yang memperkuat keterlibatan pelapor dalam tindak pidana korupsi yang dilaporkan. Perlindungan hukum juga tidak diberikan apabila terhadap pelapor dikenakan tuntutan dalam perkara lain. ${ }^{19}$

Dalam kasus seorang justice collaborator dalam peraturan ini memperoleh bantuan yang berbunyi "seorang saksi yang juga tersangka dalam kasus yang sama tidak dapat dibebaskan dari tuntutan pidana apabila ternyata ia terbukti secara sah dan meyakinkan bersalah, tetapi kesaksiannya dapat dijadikan pertimbangan hakim dalam meringankan pidana yang akan dijatuhkan". Berdasarkan peraturan tersebut untuk menciptakan keadilan dan kedudukan yang sama di mata hukum, seorang justice collaborator tetap mendapatkan hukuman meskipun telah membantu aparat dan mengembalikan harta kekayaan hasil tindak pidana korupsi.

4. Surat Edaran Mahkamah Agung No. 4 Tahun 2011 tentang Perlakukan bagi Pelapor Tindak Pidana (whistleblower) dan saksi pelaku yang

\footnotetext{
18 ibid.

${ }^{19}$ Pasal 5 ayat (3) PP No. 71 Tahun 2000.
} 
bekerjasama di dalam perkara tindak pidana tertentu.

Peraturan ini dibuat sebagai aturan yang menjelaskan secara eksplisit JC dan WB. Peran dari JC dan WB sangat dibutuhkan untuk mengungkap berbagai macam tindak pidana yang terorganisir. Dalam ayat (2) dikatakan bahwa tujuan dari SEMA No. 4 Tahun 2011 adalah untuk menumbuhkan partisipasi publik guna mengungkap tindak pidana.

Pada SEMA No. 4 Tahun 2011 dijelaskan mengenai pedoman untuk menentukan seseorang sebagai JC dan WB. Seseorang dapat dikatakan sebagai justice collaborator apabila yang bersangkutan merupakan salah satu pelaku tindak pidana tertentu sebagaimana dimaksud dalam SEMA ini, mengakui kejahatan yang dilakukannya, bukan pelaku utama dalam kejahatan tersebut serta memberikan keterangan sebagai saksi di dalam proses peradilan. Jaksa penuntut Umum di dalam tuntutannya menyatakan bahwa yang bersangkutan telah memberikan keterangan dan bukit-bukti yang sangat signifikan sehingga penyidik dan/atau penuntut umum dapat mengungkap tindak pidana dimaksud secara efektif, mengungkap pelaku-pelaku lainnya yang memiliki peran lebih besar dan/atas mengembalikan aset-aset/hasil suatu tindak pidana. ${ }^{20}$

Kategori seseorang dapat disebut sebagai whistleblower karena orang tersebut tahu tentang suatu tindak pidana dan melaporkannya. Namun, pelapor tersebut tidak termasuk dalam pihak yang melakukan tindak pidana, ini berlainan dengan justice collaborator, yang memang masuk sebagai pelaku tindak pidana. SEMA juga mengatur terkait dengan prioritas laporan dari WB harus didahulukan dengan laporan dari orang yang dilaporkan oleh WB. Ini dapat terjadi sebagai balas dendam dari pihak yang dilaporkan oleh WB. ${ }^{21}$

Menurut Sanjani pengaturan mengenai JC dan WB secara eksplisit hanya dijelaskan pada SEMA No. 4 Tahun 2011 dan peraturan bersama tentang perlakuan bagi JC dan WB di dalam perkara pidana tertentu, sehingga SEMA dan peraturan bersama tidak mempunyai kekuatan hukum yang mengikat seperti halnya undang-undang, artinya ini sifatnya terbatas pada lingkungan internal Mahkamah Agung. ${ }^{22}$

\footnotetext{
${ }^{20}$ SEMA No. 4 Tahun 2011

21 ibid.

22 Sanjani. op.cit., h. 9.
}

5. Peraturan Bersama Aparat Penegak Hukum dan LPSK tentang Perlindungan Bagi Pelapor, Saksi Pelapor, dan Saksi Pelaku yang Bekerjasama. Adanya peraturan bersama bertujuan agar ada persamaan perspektif dan pandangan antar penegak hukum. Hal ini juga sebagai sarana untuk memperlancar proses penegakan hukum untuk mengungkap dalang dari suatu tindak pidana yang terorganisir. Aturan bersama juga dijadikan sebagai pedoman bagi lembaga penegak hukum di Indonesia, sehingga antar lembaga dapat terkoordinasi untuk menangani JC dan WB.

Lembaga yang terkait dalam peraturan bersama ini yaitu Menteri Hukum dan Hak Asasi Manusia (HAM), Jaksa Agung Republik Indonesia, Kepala Kepolisian Negara Republik Indonesia, Komisi Pemberantasan Korupsi Republik Indonesia, dan LPSK RI.

Adapun tujuan dari adanya peraturan bersama yaitu agar terwujudnya sinergi lembaga penegak hukum ketika menangani tindak pidana yang terorganisir. Hal ini dilakukan dengan upaya memperoleh informasi dari JC dan WB. Kemudian adanya jaminan bagi JC dan WB serta memberikan penghargaan bagi WB yang memberikan laporan terkait tindak pidana terorganisir. ${ }^{23}$

Adapun pengaturan berkaitan dengan Justice Collaborator diatur dalam Pasal 1 sebagai berikut, poin (3): Saksi pelaku yang bekerjasama adalah saksi yang juga sebagai pelaku suatu tindak pidana yang bersedia membantu aparat penegak hukum untuk mengungkap suatu tindak pidana atau akan terjadinya suatu tindak pidana untuk mengembalikan aset-aset atau hasil suatu tindak pidana kepada negara dengan memberikan informasi kepada aparat penegak hukum, serta memberikan kesaksian di dalam proses peradilan. ${ }^{24}$

Dengan demikian aturan-aturan mengenai tindak tanduk serta perlakuan terhadap Justice Collaborator perlu diperhatikan lebih dalam lagi, sehingga seseorang yang terlibat baik Whistleblower maupun Justice Collaborator bahkan aparat kepolisian dapat lebih leluasa serta lebih baik bekerja dalam membongkar suatu kejahatan terorganisir. Maka dari itu, aturan hukum tentang Whistleblower dan Justice Collaborator perlu diatur ulang, mengingat SEMA

\footnotetext{
${ }^{23}$ Manalu. op.cit., h. 160.

24 ibid.
} 
serta peraturan bersama belum mengikat secara luas. Ada baiknya pemerintah membuat undang-undang yang mana berisi aturan-aturan baru tentang hal-hal yang harus mereka lakukan, solusi perlindungan mereka, serta penghargaan bagi mereka yang mengungkap suatu peristiwa kejahatan yang terjadi. ${ }^{25}$

\section{Undang-Undang Nomor 31 Tahun 2014 tentang Perlindungan Saksi dan Korban.}

UU No. 31 Tahun 2014 yang merupakan UndangUndang Perubahan Atas UU No. 13 Tahun 2006 tentang Perlindungan Saksi dan Korban. Perubahan ini dilakukan karena jaminan perlindungan terhadap saki dan korban memiliki peran penting dalam proses peradilan pidana. Sebelumnya, LPSK menemukan sejumlah kelemahan yang cukup signifikan pada UU No. 13 Tahun 2006, kelemahan tersebut yaitu:

a. Terdapat pengertian-pengertian kunci yang belum dicantumkan dalam Undang-Undang Nomor 13 Tahun 2006.

b. Pengertian-pengertian kunci yang ada dalam Undang-Undang Nomor 13 Tahun 2006 yang sudah tercantum tetapi belum diperjelas rumusnya.

c. Perbaikan rumusan pasal Undang-Undang mengenai kelembagaan, kewenangan yang menyangkut substansi penjabaran tugas dan fungsi LPSK, dan koordinasi antar lembaga penegak hukum.

d. Terkait adanya isu spesifik seperti pelapor (whistleblower) dan saksi pelaku yang bekerjasama mengungkap kejahatan (justice collaborator).

e. Penambahan rumusan pasal mengenai kelembagaan, kewenangan yang menyangkut tugas dan fungsi LPSK dan hubungan antar lembaga dalam melaksanakan perlindungan. ${ }^{26}$

Dalam UU No. 31 Tahun 2014 terdapat 14 (empat belas) perubahan pada UU No. 13 Tahun 2006. Perubahan penting pada Pasal 1 mengenai definisi dan ketentuan umum tentang pelapor, saksi pelaku, kompensasi dan restitusi. Meski demikian peraturan mengenai JC dan WB memiliki kelemahan. ${ }^{27}$

\footnotetext{
25 ibid.

${ }^{26}$ Undang-Undang No. 31 Tahun 2014.

${ }^{27}$ Zhulfiana Pratiwi. (2014). "Justice Collaborator Ditinjau dari Undang-Undang Nomor 31 Tahun 2014 Perlindungan Saksi dan Korban”. Jurnal Al-Qadau. 6(1), h. 39-58.
}

\section{Pelaksanaan Justice Collaborator dan} Whistleblower pada Tindak Pidana Korupsi

1. Peran Justice Collaborator dan Whistleblower dalam Mengungkap Tindak Pidana Korupsi

Korupsi merupakan salah satu kategori kejahatan yang dikategorikan sebagai kejahatan terorganisir (organized crime). Pelaku tindak pidana korupsi rata-rata berasal dari pihak-pihak yang memiliki kekuasaan dan memegang posisi-posisi strategis baik di eksekutif, legislatif, dan yudikatif. Berdasarkan hal itu, tidak diragukan lagi bahwa tindak pidana korupsi merupakan white collar crime, sehingga modus operasinya sangat dinamis yang sangat sulit memperoleh prosedural pembuktiannya. Sulitnya menemukan fakta-fakta dalam modus operasi tindak pidana korupsi membuat penegakan hukum melakukan terobosan. Terobosan yang terjadi adalah menemukan informasi melalui JC dan WB.

Pada pembahasan ini menyangkut tema pada penelitian ini mengenai peran JC dan WB dalam sistem peradilan pidana. Pembahasan pada tema ini lebih mengkhususkan pada tindak pidana korupsi di Indonesia. Seperti yang telah diketahui bahwa dalam sistem peradilan pidana ada beberapa tahapan yaitu: tahap penyelidikan, penyidikan, penuntutan, pemeriksaan pengadilan dan pelaksanaan putusan. Untuk mengetahui peran JC dan WB dalam sistem peradilan pidana berikut dijelaskan pada setiap tahap sistem peradilan pidana. ${ }^{28}$

a. Tahap Penyelidikan dan Penyidikan

Tahap ini merupakan tahap awal dari sistem peradilan pidana. Pada tahap ini penting untuk mencari dan menemukan suatu fakta kebenaran materiil berkaitan dengan peristiwa yang terjadi. Proses penemuan fakta-fakta dapat berasal dari penerimaan laporan, mencari keterangan dan barang bukit, serta aktivitas lainnya. Pada proses penyidikan, penyidik dapat melakukan tindakan pertama di tempat kejadian, pemanggilan dan pemeriksaan tersangka dan saksi serta melakukan upaya paksa yang diperlukan.

Menemukan fakta pada kasus ringan tidaklah sulit, tetapi jika kasus yang ditangani merupakan kasus yang terorganisir, maka sulit untuk menemukan fakta-faktanya. Pada kondisi

${ }^{28}$ Rusli Muhammad. (2015). "Pengaturan dan Urgensi Whistleblower dan Justice Collaborator dalam Sistem Peradilan Pidana". Jurnal Hukum IUS QUIA IUSTUM. 2(22), h. 203-222. 
tersebut, peran dari JC dan WB sangat diperlukan untuk membantu proses penyidikan. Peran JC dan WB dalam tahap ini adalah membantu penegak hukum untuk menemukan fakta yang berhubungan dengan kejahatan baik sebelum kejahatan dilakukan maupun sesudah kejahatan itu dilakukan.

b. Tahap Penuntutan

Tahap ini memiliki kendali di wilayah institusi kejaksaan yang memberikan kewenangan penuh pada jaksa penuntut umum. Penuntut umum dapat memproses tuntutan apabila BAP yang diberikan penyidik lengkap. BAP yang diajukan penyidik diterima kemudian di proses untuk membuat surat dakwaan. Kelengkapan BAP berdampak pada ketepatan dalam menyusun dakwaan. Meskipun demikian, penuntut umum tetap harus mencermati dan meneliti dalam proses penyusunan dakwaan, sehingga tidak terjadi kesalahan dalam merumuskan tindak pidana dan ancaman pasal-pasalnya.

Agar terhindar dari kesalahan dalam penyusunan dakwaan, dalam hal ini sumber informasi dari JC dan WB merupakan hal utama yang diperlukan. Peran JC dan WB pada tahap penuntutan adalah sebagai pencegahan adanya kesalahan dan ketidaktepatan dalam menyusun surat dakwaan, menghindari ketidaksesuaian antara uraian perbuatan dengan pasal-pasal yang didakwakan dan menjadi dasar penuntutan serta ketepatan dalam mengajukan terdakwa. ${ }^{29}$ Dengan demikian JC dan WB memiliki peran penting dalam tahap penuntutan sebagai sumber informasi yang terpercaya.

c. Tahap Pemeriksaan Pengadilan

Tahap ini memiliki kendali pada Ketua Hakim majelis, kemudian masing-masing pihak berupaya menyampaikan dan mengedepankan kepentingannya. Pada tahap ini terdapat proses pembuktian, proses ini akan berjalan lancar apabila perkara yang nilai komersialnya tidak tinggi dan tidak berdampak luas, pembuktiannya ringan dan mudah diselesaikan. Apabila perkara yang disidangkan bernilai tinggi dan berdampak luas, merugikan negara serta terorganisir, umumnya proses pembuktiannya sulit, memakan waktu yang panjang, bahkan keterangan saksi

\footnotetext{
29 ibid.
}

berubah-ubah atau bertentangan satu sama lainnya, sehingga tidak dapat menunjukkan keselarasan antara alat bukti yang didapatkan dengan keterangan saksi. ${ }^{30}$

Kondisi pembuktian yang demikian memerlukan terobosan dan inovasi baru dalam sistem peradilan pidana, tanpa perubahan, SPP akan tertinggal dan akan tetap menghasilkan putusan-putusan hukum tanpa ada daya preventif dalam menghadapi berbagai modus kejahatan. Kehadiran dan diakomodirnya JC dan WB dalam sistem peradilan pidana sangat membantu dalam pengungkapan kejahatan terutama dalam proses pembuktian dan pengambilan putusan oleh Hakim. JC dan WB akan menjadi saksi kunci dalam persidangan dan dengan keterangan yang disampaikan didukung oleh saksi lain serta alat-alat bukti lain akan memberikan dan menumbuhkan keyakinan bagi hakim dalam menjatuhkan putusannya.

JC dan WB sangat berperan penting pada proses pengungkapan suatu tindak pidana yang masuk dalam kategori kejahatan yang terorganisir. Dimana dalam praktik peradilan aparat hukum seringkali menemukan berbagai kendala yuridis dan non yuridis untuk mengungkap tuntas dan menemukan kejelasan suatu tindak pidana terutama dalam menghadirkan saksi-saksi kunci dalam proses hukum sejak penyidikan sampai proses pengadilan. ${ }^{31}$ Sejalan dengan itu, Nurma Rosyida menjelaskan peran seorang justice collaborator dalam mengungkap suatu kejahatan terorganisir sangat besar dan informasinya sangat penting untuk membantu aparat penegak hukum dalam mengungkap jaringan kejahatan yang selama ini tertutup sangat rapi. ${ }^{32}$

d. Tahap Pelaksanaan Putusan

Tahap ini merupakan tahap akhir dalam sistem peradilan pidana. Tujuan dari sub sistem ini adalah pembinaan dari penghuni Lembaga Pemasyarakatan (NAPI). Justice collaborator sebagai pelaku yang bekerja sama dengan penegak hukum telah mendapat pidana

${ }^{30} \mathrm{ibid}$.

${ }^{31}$ ibid.

${ }^{32}$ Nurma Rosyida, Kadek Deddy Permana Artha, dan dan Lintang Yudhanaka. (2020). "The Position of Justice Collaborator to Reveal Corruption in Finansial Management of Regional Government”. Yuridika. 35 (1), h. 93-111. 
dan menjalani hukumannya. Peran justice collaborator pada tahan ini tidak diperlukan lagi, karena informasi yang diberikan sudah membuat pelaku utama. Namun, pada kenyataannya justice collaborator yang sedang menjalankan putusannya, tidak kehilangan perannya. Sebagai contoh, Nazaruddin yang mengungkap beberapa kasus lain, selain kasus yang melibatkan dirinya. Kasus korupsi yang diungkap Nazaruddin yaitu pembangunan gedung MK, diklat MK, pembangunan gedung pajak, pengadaan simulator SIM, pembelian pesawat MA 60 oleh Merpati dan masih ada beberapa proyek lain. ${ }^{33}$ Dalam hal ini peran Nazaruddin yang mengungkap kasus korupsi di luar dari kasus yang melibatkan dirinya menjadikan Nazaruddin sebagai whistleblower.

Setelah mendapat penjelasan mengenai peran JC dan WB dalam sistem peradilan pidana. Ada beberapa contoh kasus yang diungkap melalui peran JC dan WB. Menurut laporan Jupri (2018) berikut adalah contoh kasus yang memperoleh peran justice collaborator dan atau whistleblower.

Tabel 1

Contoh Kasus yang Melibatkan

Justice Collaborator dan/atau Wshitleblower ${ }^{34}$

\begin{tabular}{|c|c|c|c|}
\hline No. & Nama & $\begin{array}{l}\text { Jumlah } \\
\text { Terpidana }\end{array}$ & Kasus \\
\hline 1 & $\mathrm{AC}$ & 30 orang & $\begin{array}{l}\text { Suap cek pemilihan } \\
\text { Deputi Gubernur Senior } \\
\text { Bank Indonesia }\end{array}$ \\
\hline 2 & MRM & 5 orang & Wisma Atlet \\
\hline 3 & MRM & 1 orang & $\begin{array}{l}\text { Korupsi Pembangkit } \\
\text { Listrik tenaga Surya } \\
\text { Kementerian Tenaga Kerja } \\
\text { dan Transmigrasi }\end{array}$ \\
\hline 4 & HS & 2 orang & $\begin{array}{l}\text { Pengadaan Videotron } \\
\text { Kementerian Koperasi dan } \\
\text { Usaha Kecil Menengah }\end{array}$ \\
\hline 5 & FXYY & 4 orang & $\begin{array}{l}\text { Suap Rekomendasi Tukar- } \\
\text { Menukar Kawasan Hutan } \\
\text { di Kab. Bogor }\end{array}$ \\
\hline 6 & SS.B & 4 orang & Simulator SIM \\
\hline 7 & KA & 2 orang & $\begin{array}{l}\text { Korupsi Proyek } \\
\text { Pengadaan Solar Home } \\
\text { System }\end{array}$ \\
\hline 8 & WM/MRM & 4 orang & Korupsi Hambalang \\
\hline 9 & MYB/TIP & 6 orang & Suap PTUN Medan \\
\hline
\end{tabular}

\footnotetext{
${ }^{33}$ detik.com. op.cit.

${ }^{34}$ Jupri, op.cit.
}

Tabel di atas menunjukkan adanya peran penting baik JC dan WB dalam membongkar kasus-kasus korupsi yang ada di Indonesia. Terkait dengan JC dan WB dijelaskan juga mengenai perlindungan bagi justice JC dan WB serta penghargaan bagi terdakwa yang menjadi JC.

\section{Perlindungan bagi Justice Collaborator dan Whistleblower}

Upaya untuk menanggulangi tindak pidana korupsi yang termasuk organized crime di Indonesia sangat memerlukan peran penting dari JC dan WB. Pada pelaksanaannya pihak yang menjadi JC dan WB berpotensi memperoleh ancaman. Lilik Mulyadi menjelaskan beberapa model yang ideal untuk memberikan perlindungan bagi JC dan WB. ${ }^{35}$

a. Model Partisipasi Langsung atau Aktif

Adanya keterlibatan baik JC dan WB memiliki dampak positif dalam mengusut tindak pidana korupsi, sehingga memberikan titik terang bagi penegakan hukum. Pada model ini memungkinkan peran secara aktif dari saksi korban atau pelapor dalam proses peradilan pidana seperti dilibatkan dalam tingkat pemeriksaan perkara, membantu jaksa/penuntut umum, memberi pertimbangan dalam menentukan pidana (victim opinion statemen) dan sebagainya. Model ini memiliki segi positif dan negatif, sisi positifnya adanya semangat pembalasan saksi/pelapor sehingga memberikan informasi kepada hakim. Segi negatifnya yaitu partisipasi saksi/pelaor dapat mengakibatkan konflik kepentingan yang nantinya memicu dendam baru yang mengarah pada secondary victimization. ${ }^{36}$

b. Model Partisipasi Tidak Langsung atau Pasif Model ini menekankan perlu adanya standar baku bagi pembinaan korban kejahatan (saksi korban/pelapor) yang dapat digunakan oleh polisi. Segi positif dari model ini dapat digunakan sebagai sarana pengembalian kepercayaan suatu institusi atau dinamakan integrity of the system of institutionalized trust. Saksi korban/pelapor

35 Lilik Mulyadi. (2014). "Perlindungan Hukum Wshitleblower dan Justice Collaborator dalam Upaya Penanggulangan Organized Crime di Indonesia”. Padjajaran Jurnal Ilmu Hukum. 1(3), h. 578-597.

${ }^{36}$ Surafli Noho. (2016). "Perlindungan Hukum terhadap Whistleblower Berdasarkan UU No. 31 Tahun 2014 tentang Perlindungan Saksi dan Korban". Lex Crime, 5(5), h. 69-76. 
diberikan jaminan kepentingan dalam sasana tertib sosial yang adil sehingga tercipta suasana tertib, terkendali, dan saling mempercayai.

Model ini juga memiliki manfaat lain yaitu efisiensi biaya, dengan adanya pedoman yang dibakukan maka proses peradilan pidana dapat dengan tepat mempertimbangkan kerugian yang dialami oleh saksi dan korban, sehingga dapat dengan mudah menentukan kompensasi bagi korban. Sisi negatif dari model ini adanya kewajiban-kewajiban yang dibebankan kepada polisi, jaksa dan pengadilan untuk melakukan tindakan-tindakan tertentu kepada saksi dan atau korban. Hal ini dianggap merugikan karena membebani aparat penegak hukum karena semuanya didasarkan atas sarana dan prasarana yang sama. Model ini menentukan standar baku tentang pelayanan terhadap saksi korban yang dilakukan oleh polisi, jaksa dan hakim. ${ }^{37}$

c. Model Persuasif/Partisipatif

Model ini memberikan perlindungan secara menyeluruh bagi JC dan WB. Model ini melibatkan kepolisian, kejaksaan, pengadilan, lembaga permasyarakatan, dan KPK. Model persuasif ini sesuai sistem peradilan pidana dalam arti sempit terlihat pada bagan berikut. Bagan 1.

Model Persuasif/Partisipatif sesuai Sistem Peradilan Pidana dalam Arti Sempit

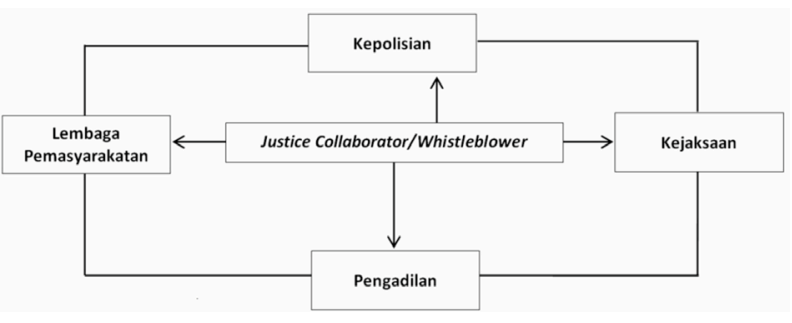

Menurut Lilik Mulyadi model ini memberikan permasalahan tentang eksistensi LPSK. LPSK seharusnya dimasukkan dalam komponen sistem peradilan pidana yang diperluas dalam KUHAP. Hal ini juga berlaku jika ingin membangun lembaga baru yang bersifat independen yang secara khusus menangani kasus JC dan WB. Maka dari itu Lilik Mulyadi memberikan gambaran mengenai model persuasif/partisipatif sesuai sistem peradilan pidana dalam arti luas.

\footnotetext{
37 ibid.
}

Bagan 2.

Model Persuasif/Partisipatif sesuai Sistem Peradilan Pidana dalam Arti Luas

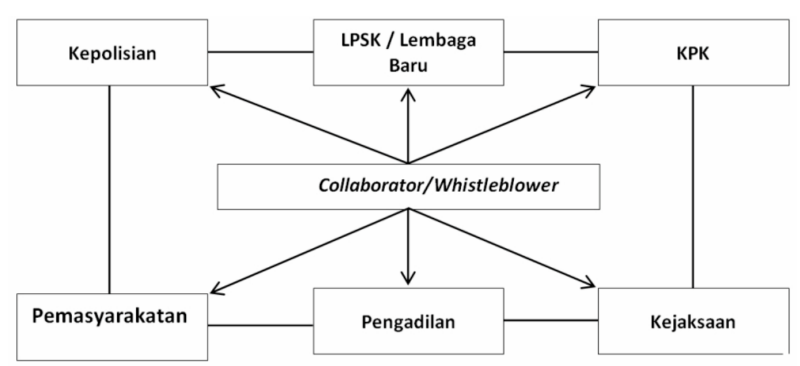

Berdasarkan model ini apabila pihak yang menjadi justice collaborator atau whistleblower melapor kepada satu lembaga saja, maka seluruh komponen lembaga tersebut akan melindunginya. Sisi positif dari model ini yaitu dapat menghindari kriminalisasi JC dan WB. Model ini memberikan rasa aman, mengurangi rasa takut pada tuntutan pidana dan perdata serta mempunyai dimensi kepastian hukum (rechtszekerheid) bagi JC dan WB.

d. Model Perlindungan Komprehensif

Model ini digagas oleh Yutirsa Yunus, yang mengedepankan perlindungan bagi JC dan WB harus dilakukan secara menyeluruh. Perlindungan bagi JC dan WB harus meliputi: (1) tahap pemberian laporan oleh JC dan WB, (2) tahap penindakan lanjutan laporan yang terdiri dari penyelidikan, penyidikan dan pengadilan, dan (3) tahap putusan oleh pengadilan atas kasus korupsi yang dilaporkan tersebut. Maksud dari perlindungan komprehensif agar JC dan WB dituntut oleh pihak yang merasa dirugikan atas laporannya, namun tuntutan balik tersebut justru memberikan dampak negatif bagi upaya pemberantasan korupsi, sehingga bagi JC dan WB putusan pengadilan yang dijatuhkan bersifat tetap (inkracht) atas kasus yang dilaporkannya tersebut. $^{38}$

e. Model Penjatuhan Pidana Bersyarat

Model ini mengelaborasikan SEM RI Nomor 4 Tahun 2011 dan ketentuan pada Pasal 37 Ayat (2) UNCAC/Konvensi PBB Anti Korupsi 2003. Dari konvensi ini dijelaskan bahwa baik JC dan WB adalah orang yang tahu dan memberikan

38 Yutirsa Yunus. (2013). "Rekomendasi Kebijakan Perlindungan Hukum Justice Collaborator: Solusi Akselerasi Pelaporan Tindak Pidana Korupsi di Indonesia”. Konfrensi Kebijakan Perencanaan Pembangunaan Nasional 2013, h. 15. 
laporan suatu tindak pidana dan bukan termasuk dari pelaku kejahatan tersebut. Jaksa Penuntut Umum Atas peran yang bersangkutan, maka dapat dijatuhkan pidana bersyarat khusus, atau pidana penjara paling ringan di antara terdakwa lainnya yang terbukti bersalah dalam perkara tersebut. Dalam pemberian perlakuan khusus berupa keringanan pidana, hakim wajib mempertimbangkan keadilan masyarakat. Hakikat model ini sesuai dengan ketentuan Pasal 37 ayat (2) UNCAC/Konvensi PBB An Korupsi 2003 yang berbunyi, Setiap negara peserta wajib mempertimbangkan kemungkinan dalam kasuskasus tertentu, memberi keringanan hukuman bagi seorang pelaku yang memberikan peran penting pada proses penyelidikan dan penuntutan suatu tindak pidana yang ditetapkan pada saat konvensi.

f. Model Perlindungan Melalui Teleconference Bentuk perlindungan lain bagi JC dan WB yang berpotensi memperoleh ancaman ketika dilakukan pemeriksaan di persidangan adalah melalui teleconference. Pemeriksaan menggunakan teleconference dalam hukum positif Indonesia belum diatur, namun pada praktiknya telah dikenal dan dilakukan. Teleconference sebagai bentuk kemajuan teknologi dalam hukum acara pidana dapat dijadikan salah satu cara untuk mendapatkan kebenaran material sehingga sangat memungkinkan dan rasional untuk dipergunakan dalam pemeriksaan di persidangan terhadap JC dan WB.

3. Pemberian Penghargaan Keringanan Bagi Justice

\section{Collaborator}

SEMA Nomor 4 Tahun 2014 menjelaskan bahwa seorang whistleblower merupakan pihak yang mengetahui dan melaporkan tindak pidana tertentu dan bukan merupakan bagian dari pelaku kejahatan yang dilaporkannya. Untuk justice collaborator merupakan salah satu pelaku tindak pidana tertentu, mengakui kejahatan yang dilakukannya, tetapi bukan sebagai pelaku utama dalam kejahatan tersebut serta memberikan keterangan sebagai saksi dalam proses peradilan.

Untuk whistleblower yang memang bukan pelaku kejahatan, maka tidak ada penghargaan yang dapat diberikan melainkan diberikan perlindungan bagi whistleblower apabila terjadi kemungkinan ancaman bagi dirinya atas tindakaan kooperatif yang dilakukan olehnya.

Penghargaan atau reward lebih ditunjukkan bagi justice collaborator yang diberikan atas kerjasama yang bersangkutan dalam membongkar tindak pidana yang terorganisir. Menurut Lilik Mulyadi penghargaan layak diberikan sebagai penegasan bahwa yang bersangkutan telah berjasa bagi upaya penegakan hukum, implikasinya ketika terdapat penghargaan terhadap justice collaborator, pelakupelaku yang lain akan berani juga mengungkap suatu tindak pidana kepada penegak hukum. ${ }^{39}$

Penghargaan kepada peran JC juga dasarnya diambil dari konvensi PBB anti korupsi, 2003 Pasa 37 yang mengatur tentang penghargaan bagi saksi pelaku yang bekerjasama, diantaranya:

a. Setiap negara peserta wajib mempertimbangkan, memberikan kemungkinan dalam kasus-kasus tertentu untuk mengurangi hukuman dari seorang pelaku yang memberikan kerjasama yang substansial dalam penyelidikan atau penuntutan suatu kejahatan korupsi.

b. Setiap negara peserta wajib mempertimbangkan kemungkinan sesuai dengan prinsip-prinsip dasar hukum nasionalnya untuk memberikan kekebalan dari penuntutan bagi orang yang memberikan kerjasama substansial dalam penyelidikan atau penuntutan (justice collaborator) suatu tindak pidana korupsi.

Peraturan di Indonesia yang menjelaskan mengenai penghargaan bagi justice collaborator diatur dalam Pasal 10A UU Nomor 13 Tahun 2006 jo UU Nomor 31 Tahun 2014 tentang Perlindungan Saksi dan Korban yakni untuk memperoleh penghargaan berupa penurunan vonis dan LPSK merekomendasikan pihak terkait kepada jaksa penuntut umum agar memuat dalam tuntutannya kepada hakim.

Lebih lanjut lagi dalam SEMA Nomor 11 Tahun 2014 dijelaskan bahwa atas bantuan justice collaborator, maka hakim dalam menjatuhkan pidana sebagaimana Pasal 9 pon (c), dapat berupa menjatuhkan pidana percobaan bersyarat khusus, dan/ atau menjatuhkan pidana berupa pidana paling ringan diantara terdakwa lain yang terbukti bersalah dalam perkara yang dimaksud.

\footnotetext{
39 ibid.
} 
Peraturan-peraturan baik secara global maupun di Indonesia menjelaskan bahwa peran dari justice collaborator patut mendapat penghargaan. Adapun pemberian penghargaan dalam bentuk memberikan pidana yang paling ringan atau pidana percobaan dengan syarat khusus. Contoh mengenai pemberian keringanan pada hukuman adalah kasus Nazaruddin yang terkait dengan suap dan pencucian uang yang mendapat remisi 4 tahun 1 bulan. Meski remisi yang diterima mendapat polemik dari berbagai pihak, namun apabila Nazaruddin memang berperan sebagai justice collaborator, maka remisi yang diterimanya merupakan penghargaan atas perannya sebagai JC.

\section{Kendala Pemberian Penghargaan bagi Justice Collaborator}

Walaupun dari sisi regulasi telah mengatur jaminan pemberian penghargaan berupa keringanan penjatuhan sanksi pidana bagi Justice Collaborator tindak pidana korupsi, faktanya dalam beberapa kasus korupsi yang diperiksa di Pengadilan Tipikor keringanan penjatuhan sanksi pidana masih terabaikan. Contohnya terlihat dalam kasus Pengadaan Solar Home System dan kasus Suap Rekomendasi Tukar-Menukar Kawasan Hutan di Kabupaten Bogor.

Pengaturan reward dalam Undang-Undang Nomor 13 Tahun 2006 jo UU Nomor 31 Tahun 2014 tidak memiliki daya ikat bagi hakim untuk mengikutinya. Hal ini karena pada proses menjalankan tugasnya, seorang Hakim tunduk pada UU 48 thn 2009 tentang Kekuasaan Kehakiman. Pada Pasal 3 ayat (1) dijelaskan bahwa dalam menjalankan tugas dan fungsinya, hakim harus menjaga kemandiriannya. Maksud dari kemandirian adalah bebas dari intervensi.

Selain itu, berkaitan dengan SEMA Nomor 4 Tahun 2011. Mahkamah Agung memberikan rekomendasi untuk memberikan penanganan khusus bagi Justice Collaborator dan Whistleblower. Berdasarkan wawancara sejumlah hakim terkait sikap mereka terhadap Surat Edaran Mahkamah Agung Nomor 4 Tahun 2011 mengemukakan bahwa SEMA bukanlah kewajiban yang harus diikuti oleh Hakim, SEMA hanyalah pedoman-pedoman bila menemukan perkara yang melibatkan seorang Justice Collaborator, tetapi terkait putusan seorang Hakim tetap independen.

\section{PENUTUP \\ Kesimpulan}

Justice collaborator dan whistleblower sangat berbeda, justice collaborator (JC) merupakan orang yang terlibat dalam suatu tindak pidana tetapi bukan pelaku utama. Sedangkan whistleblower (WB) merupakan pelapor tindak pidana dimana orang yang melaporkan tidak terlibat dalam tindak pidana yang diadukan. Pengaturan mengenai JC dan WB didasarkan atas konvensi PBB, peraturan perundangundangan, SEMA dan peraturan bersama. Meski demikian dalam praktiknya, peraturan-peraturan yang ada masih memiliki kelemahan, khususnya kewenangan dari masing-masing lembaga penegak hukum siapa yang berhak menentukan status justice collaborator atau whistleblower. Fenomena Nazaruddin yang mendapat remisi empat tahun satu bulan mengalami perdebatan antar lembaga penegak hukum, bahwa hal ini tidak seharusnya terjadi apabila peraturan-peraturan yang ada diimplementasikan dengan sebaik-baiknya.

Proses penegakan hukum yang diharapkan dengan memperbaiki penerapan antara JC dan WB. Sehingga jika terjadi seperti yang dialami Nazaruddin, dapat secara jelas statusnya apakah JC atau WB. Keduanya memiliki peran yang sama sebagai pelapor, tetapi konsekuensi antara JC dan WB berbeda. JC dapat diberikan keringanan hukum atas kasusnya, sedangkan WB karena pelapor tidak telibat dalam kasus yang dilaporkannya, maka tidak ada keringanan apapun.

JC dan WB sangat memiliki peran penting untuk mengungkap kasus-kasus korupsi yang termasuk pada kejahatan yang terorganisir. Peran dari JC dan WB dalam sistem peradilan berada pada tahap penyelidikan, penyidikan, penuntutan, pemeriksaan pengadilan, dan bahkan hingga tahap pelaksanaan putusan. Adanya peran penting dari JC dan WB dalam memberikan kesaksian atas kasus korupsi, maka memungkinkan timbul ancaman.

\section{Rekomendasi}

Perlindungan bagi JC dan WB perlu dipertimbangkan dengan berbagai model untuk meningkatkan partisipasi pihak-pihak dalam melaporkan kasus yang diketahuinya, maka JC dan WB perlu diberikan penghargaan (reward). 


\section{DAFTAR PUSTAKA}

\section{Peraturan Perundangan-Undangan:}

Peraturan Pemerintah Nomor 71 Tahun 2000 tentang Tata Cara Pelaksanaan Peran Serta Masyarakat dan Pemberian Penghargaan dalam Pencegahan dan Pemberantasan Tindak Pidana Korupsi.

Peraturan Pemerintah Nomor 99 Tahun 2012 tentang Perubahan Kedua atas Peraturan Pemerintah Nomor 32 Tahun 1999 tentang Syarat dan Tata Cara Pelaksanaan Hak Warga Binaan Pemasyarakatan.

Surat Edaran Mahkamah Agung Nomor 04 Tahun 2011 tentang Perlakuan Bagi Pelapor Tindak Pidana (Whistleblower) dan Saksi Pelaku yang Bekerjasama (Justice Collaborators) di dalam Perkara Tindak Pidana Tertentu.

Undang-Undang Nomor 13 Tahun 2006 tentang Perlindungan Saksi dan Korban.

Undang-Undang Nomor 31 Tahun 2014 tentang Perlindungan Saksi dan Korban.

\section{Buku:}

Abdul Haris Semendawai. (2011). Memahami Whistleblower. Jakarta: Lembaga Perlindungan Saksi dan Korban (LPSK).

Yutirsa Yunus. (2013). "Rekomendasi Kebijakan Perlindungan Hukum Justice Collaborator: Solusi Akselerasi Pelaporan Tindak Pidana Korupsi di Indonesia". Konfrensi Kebijakan Perencanaan Pembangunaan Nasional 2013.

\section{Jurnal:}

Fadli Razeb Sanjani. (2015). "Penerapan Justice Collaborator dalam Sistem Peradilan Pidana di Indonesia". JOM Fakultas Hukum, 2(2), h. 1-14.

Firman Wijaya. (2012). Whistle Blower dan Justice Collaborator dalam Perspektif Hukum. Jakarta: Penaku.

Hambali Thalib, Sufirman Rahman, dan Abdul Haris. (2017). "The Role of Justice Collaborator in Uncovering Criminal Case in Indonesia". Diponegoro Law Review,2(1), h. 1-16.

Jupri. (2018). "Reward Keringanan Sanksi Pidana Bagi Justice Collaborator Perkara Korupsi”. Jurnal Transformative, 4(1), h. 13-32.

Lilik Mulyadi. (2014). "Perlindungan Hukum Wshitleblower dan Justice Collaborator dalam Upaya Penanggulangan Organized Crime di
Indonesia”. Padjajaran Jurnal Ilmu Hukum. 1(3), h. 578-597.

Nurma Rosyida, Kadek Deddy Permana Artha, dan dan Lintang Yudhanaka. (2020). "The Position of Justice Collaborator to Reveal Corruption in Finansial Management of Regional Government". Yuridika. 35 (1), h. 93-111.

Puteri Hikmawati. (2013). "Upaya Perlindungan Whistleblower dan Justice Collaborator dalam Tindak Pidana Korupsi”. Negara Hukum. 4(1), h. 87-104.

River Yohanes Manalu. (2015). "Justice Collaborator dalam Tindak Pidana Korupsi". Lex Crimen, 4(1), h. 152-163.

Rusli Muhammad. (2015). "Pengaturan dan Urgensi Whistleblower dan Justice Collaborator dalam Sistem Peradilan Pidana”. Jurnal Hukum IUS QUIA IUSTUM. 2(22), h. 203-222.

Surafli Noho. (2016). "Perlindungan Hukum terhadap Whistleblower Berdasarkan UU No. 31 Tahun 2014 tentang Perlindungan Saksi dan Korban". Lex Crime, 5(5), h. 69-76.

Zainal Arifin Hoesein. (2012). "Pembentukan Hukum dalam Perspektif Pembaruan Hukum”. Jurnal RechtsVinding. 1(3), h. 307-327.

Zhulfiana Pratiwi Hafid. (2014). "Justice Collaborator Ditinjau dari Undang-Undang Nomor 31 Tahun 2014 Perlindungan Saksi dan Korban”. Jurnal Al-Qadau. 6(1), h. 39-58.

\section{Website:}

Alfian Putra Abdi. "KPK: Nazaruddin Bukan Justice Collaborator Melainkan Whistleblower". available from https://tirto.id/kpk-nazaruddinbukan-justice-collaborator-melainkanwhistleblower-fKPR?utm_source=Tirtoid\&utm medium $=$ Terkait, diakses pada 2 Mei 2020.

. "Silang Pendapat KPK dan Kemenkumham Soal Cuti Bebas Nazaruddin". available from https://tirto.id/silang-pendapat-kpk-dankemenkumham-soal-cuti-bebas-nazaruddinfJAu, diakses pada 2 Mei 2020.

CNN Indonesia. "Soal Nazaruddin bebas, Yasonna Berdalih Ada Surat KPK”. available from https://www.cnnindonesia.com/ nasional/20200623002626-12-516220/soalnazaruddin-bebas-yasonna-berdalih-ada-surat$k p k$, diakses pada 2 Mei 2020. 
Ibnu Hariyanto. "Pimpinan KPK: Nazaruddin Bukan Justice Collaborator, Tapi Whistleblower". available from https://news. detik.com/berita/d-5065463/pimpinan-kpknazaruddin-bukan-justice-collaborator-tapiwhistleblower/1, diakses pada 1 Mei 2020.
Rakhmad Hidayatulloh Permana. "Jadi Justice Collaborator-Dapat Remisi 4 Tahun, Ini yang Diungkap Nazaruddin". available from https:// news.detik.com/berita/d-5056933/jadi-justicecollaborator-dapat-remisi-4-tahun-ini-yangdiungkap-nazaruddin/2, diakses 1 Mei 2020. 